\title{
Very high coupling of TM polarised light in photonic crystal directional couplers
}

Borel, Peter Ingo; Thorhauge, Morten; Frandsen, Lars Hagedorn; Cheng, J.; Kampanis, M.; Kristensen, Martin; Lavrinenko, Andrei; Zhuang, Yanxin; Chong, H.M.H.

\section{Published in: \\ CLEO/Europe}

Link to article, DOI:

10.1109/CLEOE.2003.1313735

Publication date:

2003

Document Version

Publisher's PDF, also known as Version of record

Link back to DTU Orbit

Citation (APA):

Borel, P. I., Thorhauge, M., Frandsen, L. H., Cheng, J., Kampanis, M., Kristensen, M., Lavrinenko, A., Zhuang, Y., \& Chong, H. M. H. (2003). Very high coupling of TM polarised light in photonic crystal directional couplers. In CLEO/Europe IEEE. https://doi.org/10.1109/CLEOE.2003.1313735

\section{General rights}

Copyright and moral rights for the publications made accessible in the public portal are retained by the authors and/or other copyright owners and it is a condition of accessing publications that users recognise and abide by the legal requirements associated with these rights.

- Users may download and print one copy of any publication from the public portal for the purpose of private study or research.

- You may not further distribute the material or use it for any profit-making activity or commercial gain

- You may freely distribute the URL identifying the publication in the public portal 


\title{
Very high coupling of TM polarised light in photonic crystal directional couplers
}

\author{
P.I. Borel, M. Thorhauge, L.H. Frandsen, J. Cheng, M. Kampanis, M. Kristensen, A. Lavrinenko, Y. Zhuang, \\ Research Center COM, Technical University of Denmark, Bldg. 345 west, DK-2800, Kgs. Lyngby, Denmark \\ H.M.H. Chong
}

Department of Electronics and Electrical Engineering, Glasgow University, Glasgow G12 8LT, Scotland, UK

Very low propagation losses in straight photonic crystal waveguides (PCWs) have previously been reported [1]. A next natural step is to add functionality to the PCWs and create ultra compact optical components. Directional couplers have been fabricated in a $\mathrm{SiO}_{2} / \mathrm{Si} / \mathrm{SiO}_{2}$ trilayer film. The photonic crystal is defined by holes with diameter $D_{\text {glass }}=0.76 \Lambda$ arranged in a triangular lattice having lattice constant $\Lambda=428 \mathrm{~nm}$. Leaving out single rows of holes creates the PCWs. Two PCWs are separated by one row of holes and the coupling length is $30 \Lambda$. The coupling channel includes two $60^{\circ}$ bends to separate the two channels from each other as illustrated in the SEM image to the right. The coupled light is recorded from a mirrored coupler in order to avoid any losses introduced by the two $60^{\circ}$ bends. The light is coupled in and out of the PCWs using tapered ridge waveguides. An optical spectrum analyser records the light from the coupled and direct channel by using two LED sources centred at $1330 \mathrm{~nm}$ and $1550 \mathrm{~nm}$. 3D

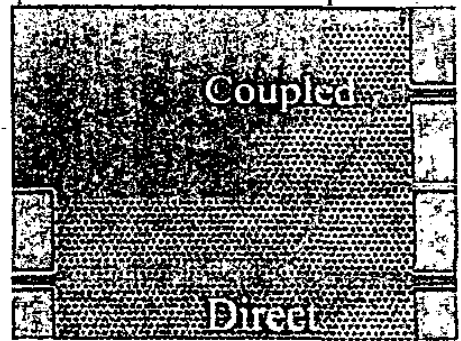
FDTD calculations utilising an improved version of the ONYX-2 code [2] are used to simulate the directional couplers. The simulated structures are identical to the experimental ones, except that the length of the intermediate straight PCW connecting the two bends is $5 \Lambda$ and $28 \Lambda$ in the simulations and experiments, respectively. The experimental and simulated spectra for TE and TM polarised light for the transmission through the direct and coupled channels are shown in the figures below. The experimental data are normalised to ridge waveguide measurements.
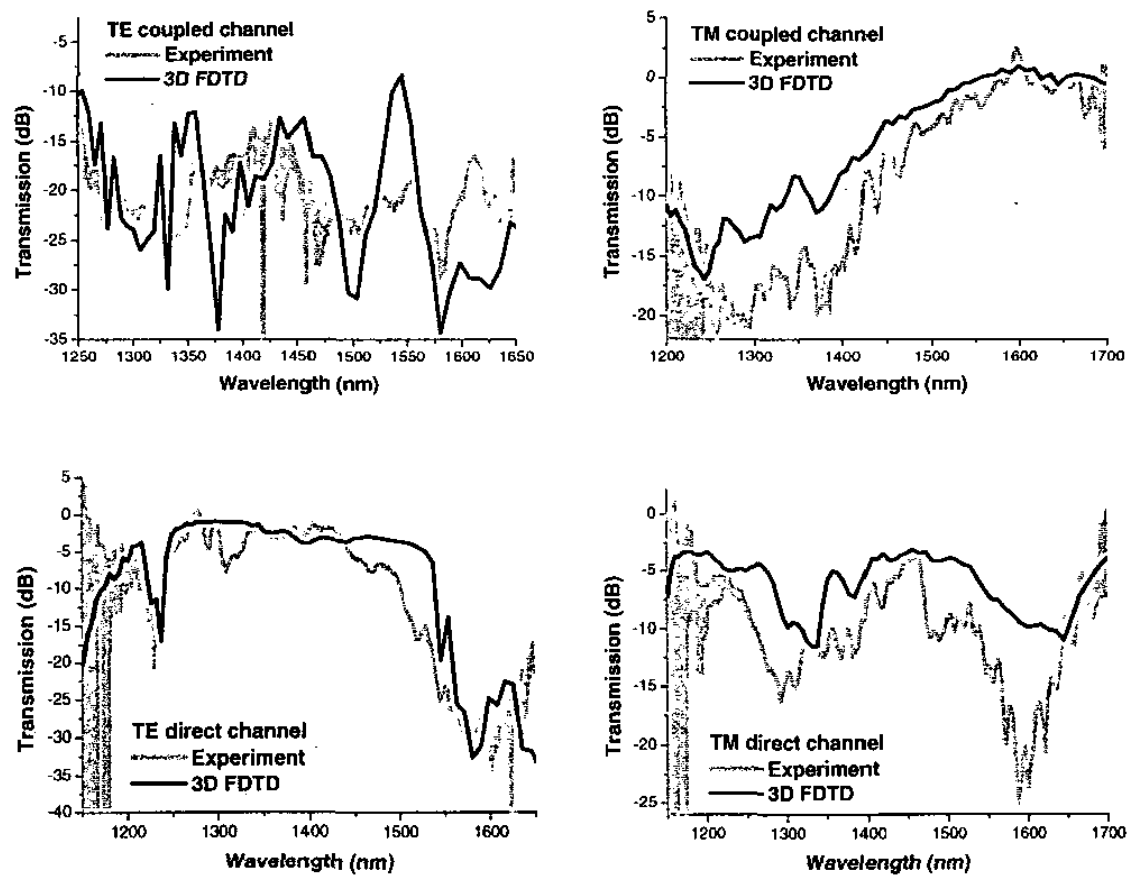

The 3D FDTD simulations successfully explain all the major features of the experimental spectra as well as the actual transmission level. Especially noteworthy is the transmission level, experimentally found to be above $-3 \mathrm{~dB}$ in the wavelength range $1520-1690 \mathrm{~nm}$, for TM polarised light in the coupled channel. It is noted that even though band calculations show that the propagation of the TM polarisation takes place below the TM valence band, very high and spectrally smooth coupling is observed for the TM polarisation in this wavelength range.

[1] J. Arentoft. T. Søndergaard, M. Kristensen. A. Boltasseva. M. Thorhauge, and L. Frandsen. "Low-loss silicon-on-insulator photonic crystal waveguides." Electron. Lett. 38, 274-275 (2002).

[2] A.J. Ward and J.B. Pendry. "A program for calculating photonic band structures. Green's functions and transmission/reflection coefticients using a non-orthogonal FDTD method", Comp. Phys. Com, 128, 590-621 (2000). 